This article was downloaded by: [National Taiwan University]

On: 31 August 2009

Access details: Access Details: [subscription number 905688740]

Publisher Taylor \& Francis

Informa Ltd Registered in England and Wales Registered Number: 1072954 Registered office: Mortimer House, 37-41 Mortimer Street, London W1T 3JH, UK

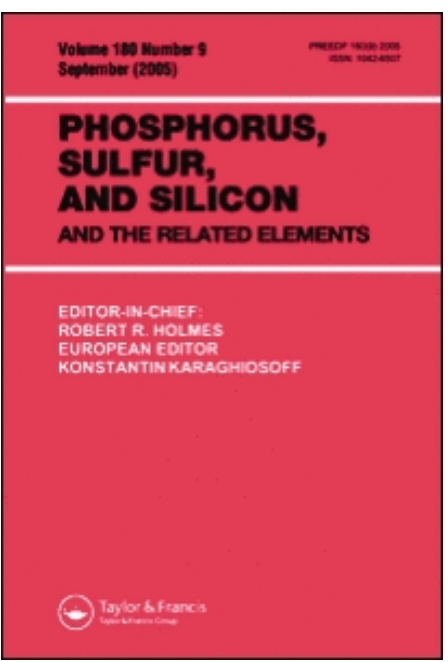

Phosphorus, Sulfur, and Silicon and the Related Elements

Publication details, including instructions for authors and subscription information: http://www.informaworld.com/smpp/title content=t713618290

\title{
NITROGEN-CONTAINING TRIPODAL PHOSPHINE LIGANDS
}

Hsing-Ell Wang a; Chung-Yuan Liu a; Ming-Chu Cheng a; Shie-Ming Peng a; Shiuh-Tzung Liu a

a Department of Chemistry, National Taiwan University, Taipei, Taiwan, R.O.C.

Online Publication Date: 01 July 1992

To cite this Article Wang, Hsing-Ell, Liu, Chung-Yuan, Cheng, Ming-Chu, Peng, Shie-Ming and Liu, Shiuh-Tzung(1992)'NITROGENCONTAINING TRIPODAL PHOSPHINE LIGANDS',Phosphorus, Sulfur, and Silicon and the Related Elements,69:3,201 — 211

To link to this Article: DOI: $10.1080 / 10426509208040638$

URL: http://dx.doi.org/10.1080/10426509208040638

\section{PLEASE SCROLL DOWN FOR ARTICLE}

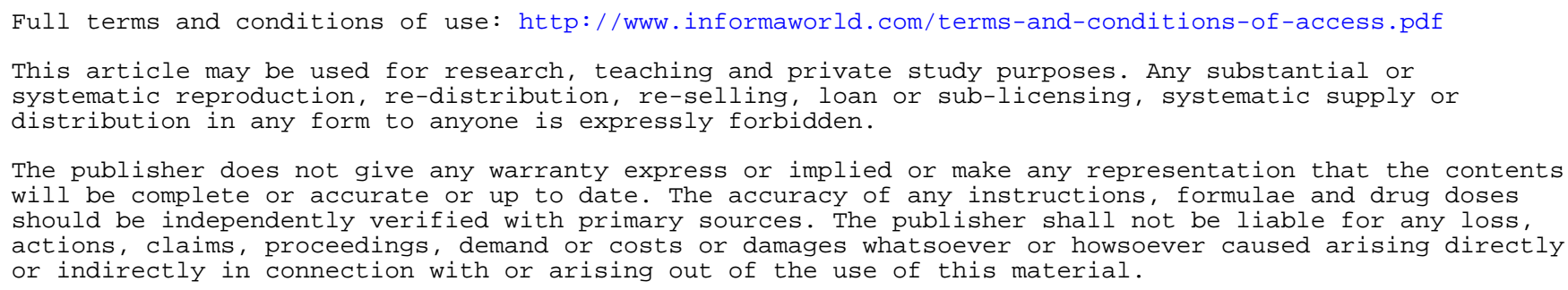

The publisher does not give any warranty express or implied or make any representation that the contents will be complete or accurate or up to date. The accuracy of any instructions, formulae and drug doses should be independently verified with primary sources. The publisher shall not be liable for any loss, actions, claims, proceedings, demand or costs or damages whatsoever or howsoever caused arising directly or indirectly in connection with or arising out of the use of this material. 


\title{
NITROGEN-CONTAINING TRIPODAL PHOSPHINE LIGANDS
}

\author{
HSING-ELL WANG, CHUNG-YUAN LIU, MING-CHU CHENG, \\ SHIE-MING PENG and SHIUH-TZUNG LIU* \\ Department of Chemistry National Taiwan University, Taipei, \\ Taiwan 107, R.O.C.
}

(Received January 1, 1992; in final form March 9, 1992)

Two tripodal phosphine ligands, 2,2-bis(diphenylphosphinomethyl)-1-(diethylamino)propane $\left(\mathbf{P}_{2} \mathbf{N}\right)$ and 2,2-bis(diethylaminomethyl)-1-diphenylphosphinopropane $\left(\mathbf{P N}_{2}\right)$ were synthesized. Palladium(II) and Platinum(II) complexes with these ligands were obtained from the reaction of $\mathrm{PdCl}_{2}\left(\mathrm{CH}_{3} \mathrm{CN}\right)_{2}$ and $\mathrm{K}_{2} \mathrm{PtCl}_{4}$ respectively. Complex $\left(\mathbf{P}_{2} \mathbf{N}\right) \mathrm{PtCl}_{2}$ crystallizes in space group $\mathrm{Pca}_{1}$ with $a=21.983(5)$, $b=11.419(1), c=14.179(3) \AA$, and the structure was refined to $R=0.039$ by using 2826 reflections.

Key words: Tripodal ligands; phosphines; nitrogen donors; hybrid donors; complexes.

\section{INTRODUCTION}

Multiple dentates containing hybrid P-N phosphines are of considerable interest in coordination chemistry and part of our research work involves the development of new tripodal phosphine ligands containing different donor systems..$^{2-5}$ In our previous study, ${ }^{3}$ an intramolecular donor exchange process was observed in 1 (Equation 1), but not in 2. Apparently, the weak coordinating ability of sulfur is responsible for this difference. The extension of this study to nitrogen donors is presented in this paper. Thus tripodal ligands, 2,2-bis(diphenylphosphinomethyl)1-(diethylamino)propane $\left(\mathbf{P}_{2} \mathbf{N}\right)$ and 2,2-bis(diethylaminomethyl)-1-diphenylphosphinopropane $\left(\mathbf{P N}_{2}\right)$, along with their palladium(II) and platinum(II) complexes are synthesized.

\section{Equation 1}<smiles>CC1(CS)CC(Pc2ccccc2)[PH](c2ccccc2)(c2ccccc2)C(Cl)(c2ccccc2)C1</smiles><smiles>C=C=CC1(C)C[SH](c2ccccc2)P(c2ccccc2)(c2ccccc2)(c2ccccc2)C(Cl)(Cl)C1</smiles>

1<smiles>CC1(CSc2ccccc2)CP(Cl)P(Cl)P(c2ccccc2)C1</smiles>

2<smiles>CCN(CC)CC(C)(CP)CPc1ccccc1</smiles>

$3\left(\mathrm{P}_{2} \mathrm{~N}\right)$

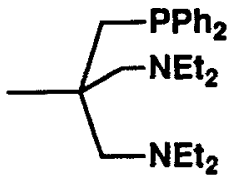

$4\left(\mathrm{PN}_{2}\right)$ 


\section{RESULTS AND DISCUSSION}

\section{Synthesis and Characterization of Ligands}

Elaboration of triol 5 into $\mathbf{P}_{\mathbf{2}} \mathbf{N}$ was quite straightforward, as shown in Scheme I. The synthetic approach to the ligand $\mathbf{P}_{2} \mathbf{N}$ is quite similar to the methods for preparation of $\mathbf{P}_{2} \mathbf{S}^{4}$, except a nitrogen nucleophile replaces the sulfur one. The conversion of triol 5 into toluenesulfonate 7 was carried out according to the literature method. ${ }^{6}$ Nucleophilic substitution of tosylate 7 by azide in $N, N$-dimethylformamide at $100^{\circ} \mathrm{C}$ produced compound 8 , which was then reduced by lithium aluminum hydride to generate the amine function 9 . The use of various nitrogen nucleophiles such as sodium dimethylamide and methylamine provided a poor yield of the desired compound. Alkylation of $\mathbf{9}$ into $\mathbf{1 0}$ was obtained in reasonable yield, by simply reacting with ethyl iodide in the presence of potassium carbonate. Deprotection of the ketal function was carried out in aqueous solution under acidic conditions to generate alcohol 11 quantitatively. The hydroxy functions were transformed into the mesylate by using $n$-BuLi followed by methanesulfonyl chloride. Without isolation of the methanesulfonate 19 , it reacted with diphenylphosphide anion to give the desired compound $\mathbf{P}_{2} \mathbf{N}$ as a viscous oil in $76 \%$ yield. It should be mentioned that attempts to isolate $\mathbf{1 9}$ resulted in cyclization to yield the ammonium salt 20 .

Preparation of $\mathbf{P}_{2} \mathbf{N}$

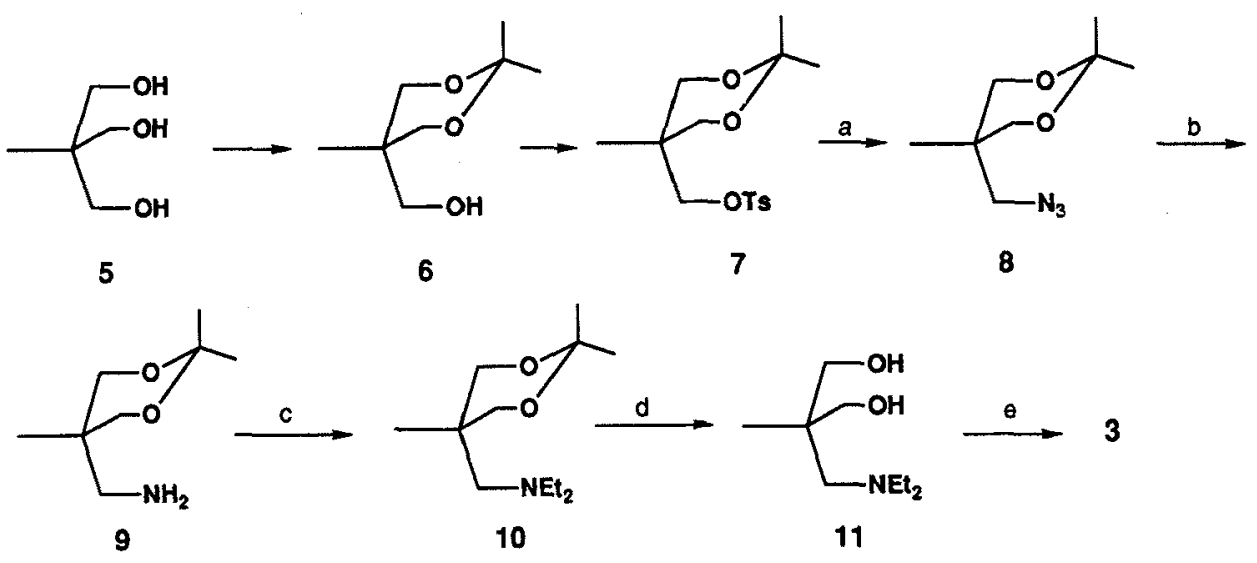

a. $\mathrm{NaN}_{3}$, DMF $75 \%$ b. $\mathrm{LiAlH}_{4} \quad 89 \%$ c. $\mathrm{CH}_{3} \mathrm{CH}_{2} \mathrm{l}, \mathrm{K}_{2} \mathrm{CO}_{3} \quad 76 \%$ d. $\mathrm{H}_{2} \mathrm{O} / \mathrm{H}^{+} \quad 97 \%$

e. (i) $\mathrm{n}$-BuLi (ii) $\mathrm{CH}_{3} \mathrm{SO}_{2} \mathrm{Cl}$ (iii) $\mathrm{Ph}_{2} \mathrm{P}^{-} \mathrm{Li}^{+} \quad 76 \%$

Scheme I

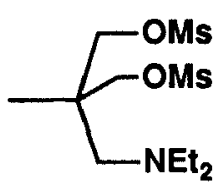

19

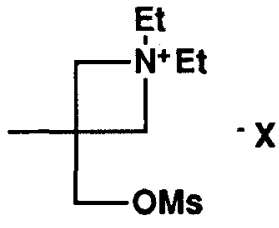

20 
The synthesis of 4 required considerably more strategy than that of 3 . The hydroxy function of 6 was protected with benzyl chloride to give 12. Hydrolysis of ketal 12 under acidic conditions regenerated the diol function which was transferred into amino groups. The introduction of diethylamino groups to give $\mathbf{1 6}$ was carried out by a method similar to that for $\mathbf{P}_{\mathbf{2}} \mathbf{N}$ (Scheme II). Deprotection of the benzyl group was performed by treating $\mathbf{1 7}$ with lithium naphthalenide in tetrahydrofuran. Alcohol 18 was transformed into the phosphine 4 in $50 \%$ yield by a procedure similar to that for conversion of $\mathbf{1 1}$ into $\mathbf{P}_{\mathbf{2}} \mathbf{N}$.

The identification of $\mathbf{P}_{\mathbf{2}} \mathbf{N}$ and $\mathbf{P N}_{\mathbf{2}}$ was carried out by spectral and elemental analysis. Phosphorus-31 NMR spectra showed absorptions at -25.02 and -24.95 ppm for $\mathbf{P}_{\mathbf{2}} \mathbf{N}$ and $\mathbf{P N}_{\mathbf{2}}$ respectively, which are typical absorptions for tertiary diarylalkylphosphines. The integrations of the methyl groups in $\mathbf{P}_{\mathbf{2}} \mathbf{N}$ and $\mathbf{P N}_{\mathbf{2}}$ in ${ }^{1} \mathbf{H}$ NMR spectra are clearly differentiated in these two species. Other spectral data along with elemental analysis (experimental section) are consistent with the assigned structures for $\mathbf{P}_{\mathbf{2}} \mathbf{N}$ and $\mathbf{P N}_{\mathbf{2}}$. The synthetic intermediates to both target molecules were also isolated and characterized.

\section{Complexation}

The palladium complexes of $\mathbf{P}_{\mathbf{2}} \mathbf{N}$ and $\mathbf{P N}_{\mathbf{2}}$ were performed by reactions of ligands with $\mathrm{PdCl}_{2}\left(\mathrm{CH}_{3} \mathrm{CN}\right)_{2}$ in dichloromethane individually, and both complexes were isolated as yellow solids. The single chemical shift at $\delta 17.1$ appeared in phosphorus$31 \mathrm{NMR}$ for the complex $\left(\mathbf{P}_{2} \mathbf{N}\right) \mathrm{PdCl}_{2}$ clearly indicated that both phosphine sites of $\mathbf{P}_{\mathbf{2}} \mathbf{N}$ were coordinated to the metal center. It is believed that this complex has square planar geometry around the palladium metal, which is similar to that of $\left(\mathbf{P}_{2} \mathbf{S}\right) \mathbf{P d C l}_{2}$. In the complex of $\left(\mathbf{P N}_{\mathbf{2}}\right) \mathrm{PdCl}_{2} \mathbf{2 2}$, the $\mathbf{P N} \mathbf{N}_{\mathbf{2}}$ ligand acts as a bidentate with the phosphorus and one of nitrogen donors coordinated to the palladium metal as evidenced by the ${ }^{1} \mathrm{H}$ NMR absorptions. The two ethyl groups of the uncoordinated nitrogen donor appears to be identical with chemical shifts for methyl at

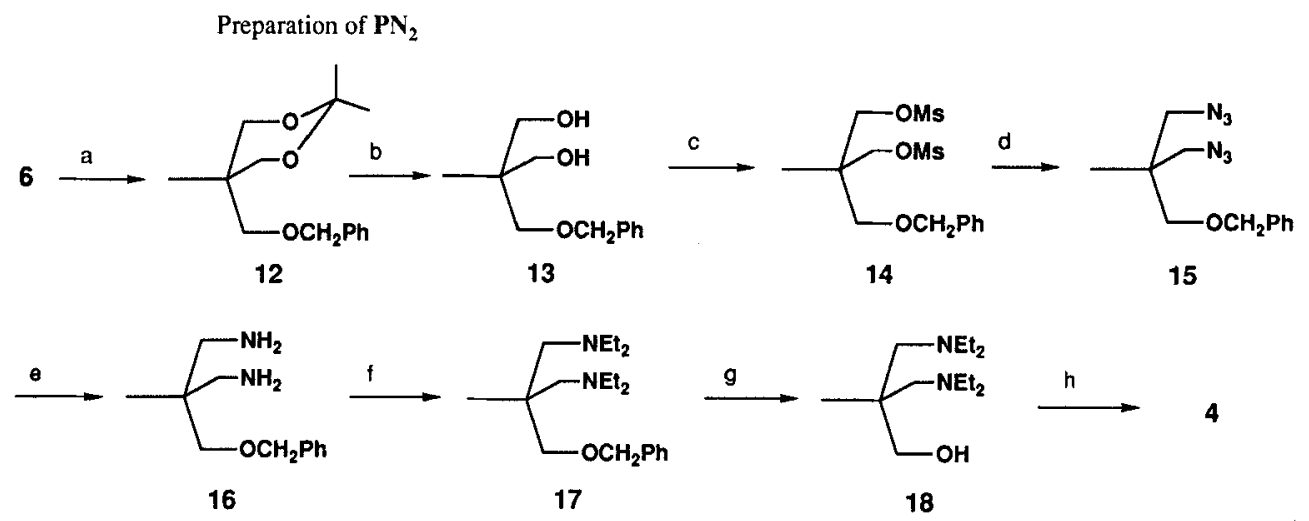

a (i) $\mathrm{Na}$ (ii) $\mathrm{PhCH}_{2} \mathrm{Cl}, 80 \%$ b. $\mathrm{H}_{2} \mathrm{O} / \mathrm{H}^{+}, 99 \%$ c. $\mathrm{MsCl}_{2} / \mathrm{Et}_{3} \mathrm{~N}, 94 \%$ d. $\mathrm{NaN}_{3} / \mathrm{DMF}, 91 \%$ e Raney Ni/i-PrOH, $89 \%$ f. $\mathrm{CH}_{3} \mathrm{CH}_{2} \mathrm{l} / \mathrm{K}_{2} \mathrm{CO}_{3} \quad 81 \%$ g. Li/naphthalene $88 \%$ h. (i) $\mathrm{n}-\mathrm{BuLi}$ (ii) $\mathrm{MsCl}$ (iii) $\mathrm{Ph}_{2} \mathrm{P}^{-} \mathrm{Li}^{+} 50 \%$ 


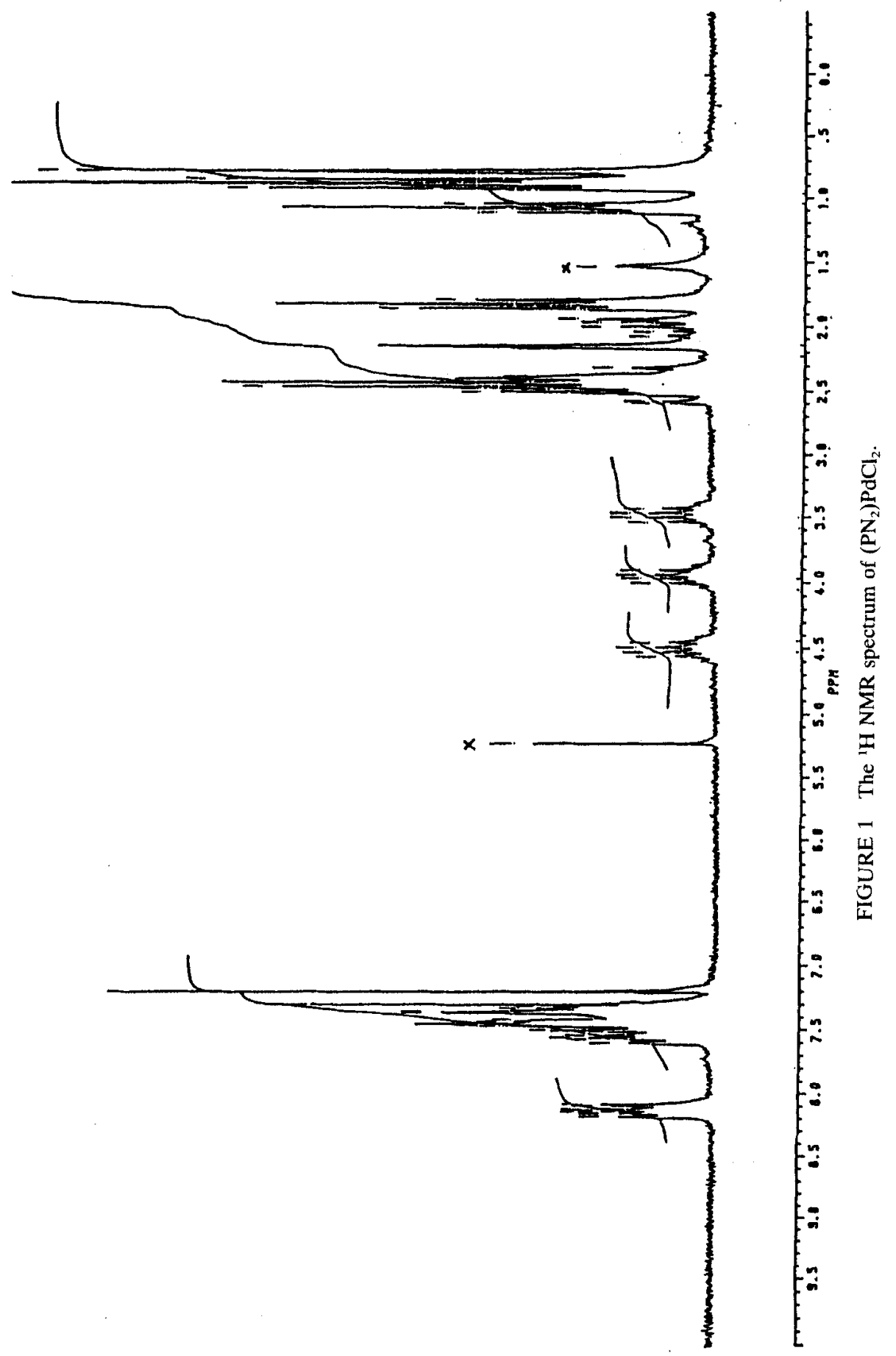


$\delta 0.92(t, J=7.1 \mathrm{~Hz})$ and methylene $\delta 2.63-2.36(\mathrm{~m})$; while the other two ethyl groups are different (Figure 1) because they are either cis or trans to the diethylaminomethyl group along the chelate ring. Variable temperature NMR studies did not show peak broadening, but decomposition occurred at a higher temperature. This result suggest that the nitrogen donor atoms are not exchanging.

Under phase transfer catalyzed conditions, the reaction of potassium tetrachloroplatinate with equal-molar $\mathbf{P}_{\mathbf{2}} \mathbf{N}$ ligand in a mixture of dichloromethane and water solvent provided $\left(\mathbf{P}_{2} \mathbf{N}\right) \mathrm{PtCl}_{2}$ in $90 \%$ yield. Besides the spectral and elemental analyses (Table I), the structure of this complex was determined by its $\mathrm{x}$-ray diffraction. The ORTEP plot is shown in Figure 2 and some important bond distances and angles are listed in Table II. As expected, the geometry of the coordinated platinum metal is square-planar. The average bond distance of $\mathrm{P}-\mathrm{Pt}$ is $2.26 \AA$, which is quite similar to that of cis- $\left(\mathrm{R}_{3} \mathrm{P}\right)_{2} \mathrm{PtCl}_{2}(2.24-2.27 \AA) .{ }^{7}$ The bond angles around the metal centers are in the normal range for platinum complex. It is worthy

TABLE I

${ }^{31} \mathrm{P}$ NMR chemical shifts and elemental analysis

\begin{tabular}{|c|c|c|}
\hline Complex & $\delta^{31} \mathrm{Pnmr}{ }^{\mathrm{a}, b}$ & Elemental analysis ${ }^{c}$ \\
\hline$\left(\mathbf{P}_{2} \mathbf{N}\right) \mathrm{PdCl}_{2}$ & $17.0[42.0]$ & $\begin{array}{l}\mathrm{C}_{33} \mathrm{H}_{39} \mathrm{Cl}_{2} \mathrm{NP}_{2} \mathrm{Pd} \\
\mathrm{C}, 57.77(57.53) \\
\mathrm{H}, 5.34(5.71) \\
\mathrm{N}, 1.81(2.03)\end{array}$ \\
\hline$\left(\mathbf{P N}_{2}\right) \mathrm{PdCl}_{2}$ & $18.06[43.0]$ & $\begin{array}{l}\mathrm{C}_{25} \mathrm{H}_{39} \mathrm{Cl}_{2} \mathrm{~N}_{2} \mathrm{PPd} 1 / 4 \mathrm{CH}_{2} \mathrm{Cl}_{2} \\
\mathrm{C}, 50.79(50.94) \\
\mathrm{H}, 6.67(6.64) \\
\mathrm{N}, 4.69(4.67)\end{array}$ \\
\hline$\left(\mathbf{P}_{2} \mathbf{N}\right) \mathrm{PtCl}_{2}$ & $-1.8\left(\mathrm{~J}_{\mathrm{Pt}-\mathrm{P}}=3388 \mathrm{~Hz}\right)[23.2]$ & $\begin{array}{l}\mathrm{C}_{33} \mathrm{H}_{39} \mathrm{Cl}_{2} \mathrm{NP}_{2} \mathrm{Pt} \mathrm{CH}_{2} \mathrm{Cl}_{2} \\
\mathrm{C}, 46.84(47.02) \\
\mathrm{H}, 4.55(4.77) \\
\mathrm{N}, 1.48(1.61)\end{array}$ \\
\hline$\left(\mathrm{PN}_{2}\right) \mathrm{PtCl}_{2}$ & $-5.64\left(\mathrm{~J}_{\mathrm{Pt}-\mathrm{P}}=3949 \mathrm{~Hz}\right)[19.2]$ & $\begin{array}{l}\mathrm{C}_{25} \mathrm{H}_{39} \mathrm{Cl}_{2} \mathrm{~N}_{2} \mathrm{PPt} \\
\mathrm{C}, 45.18(45.39) \\
\mathrm{H}, 5.92(5.71) \\
\mathrm{N}, 4.22(3.96)\end{array}$ \\
\hline
\end{tabular}

a. ppm relative $85 \% \mathrm{H}_{3} \mathrm{PO}_{4}$ in $\mathrm{CDCl}_{3}$.

b. The values in [] are coordination chemical shifts in ppm.

c. The values in () are calculated.

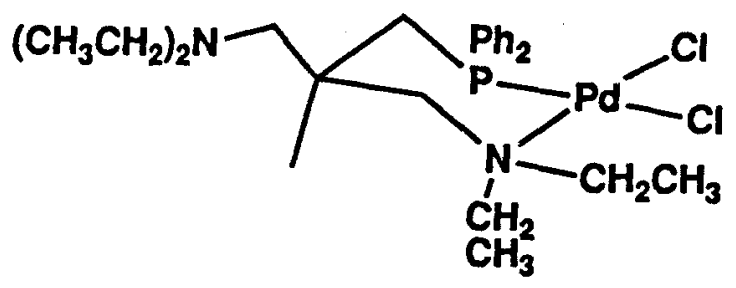




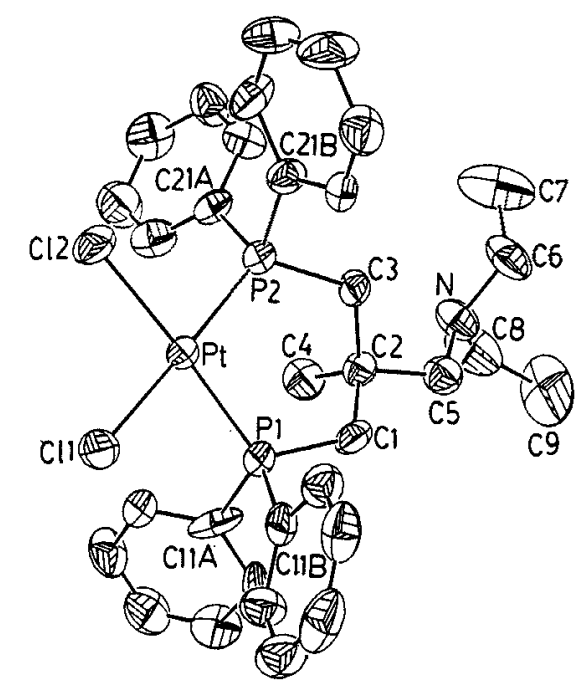

FIGURE 2 The ORTEP plot of $\left(\mathrm{P}_{2} \mathrm{~N}\right) \mathrm{PtCl}_{2}$.

of note that the conformation of six-membered chelate ring is near a half-chair form (Figure 3) as evidenced by the small dihedral angles of $\mathrm{C} 3-\mathrm{P} 2-\mathrm{Pt}-\mathrm{P} 1$ and $\mathrm{P} 2-\mathrm{Pt}-\mathrm{P} 1-\mathrm{C} 1$ (Table II). This was presumably due to the relief of the steric interaction of phenyl groups and chloride ligands. The un-coordinated diethylaminomethyl group was positioned at an equatorial orientation for avoiding the 1,3diaxial interaction with phenyl groups. A white solid of complex $\left(\mathbf{P N}_{2}\right) \mathrm{PtCl}_{2}$, was prepared similarly. The coordination of phosphorus to the metal center is clearly suggested by its ${ }^{31} \mathrm{P}$ NMR shift at $-5.62\left(\mathrm{~J}_{\mathrm{Pt}-\mathrm{P}}=3949 \mathrm{~Hz}\right)$. The ${ }^{1} \mathrm{H} \mathrm{NMR}$ spectrum of this complex also shows two different shifts for ethyl groups of coordinated nitrogen.

\section{TABLE II}

Selected bond distances $(\AA)$, bond angles (deg) and dihedral angles (deg).

\begin{tabular}{lllr}
\hline Pt-P1 & $2.253(3)$ & & \\
Pt-P2 & $2.268(3)$ & Cl1-Pt-Cl2 & $90.2(1)$ \\
Pt-Cl1 & $2.341(3)$ & Cl1-Pt-P1 & $87.2(1)$ \\
Pt-C12 & $2.336(3)$ & Cl1-Pt-P2 & $175.5(1)$ \\
P1-C1 & $1.80(1)$ & Cl2-Pt-P1 & $177.4(1)$ \\
C1-C2 & $1.51(2)$ & Cl2-Pt-P2 & $87.7(1)$ \\
C2-C3 & $1.57(2)$ & & \\
C3-P2 & $1.87(1)$ & &
\end{tabular}

Dikedral angles along Pt-P1-C1-C2-C3-P2

\begin{tabular}{lr} 
Pt-P1-C1-C2 & $-45(1)$ \\
P1-C1-C2-C3 & $76(1)$ \\
C1-C2-C3-P2 & $-70(1)$ \\
C2-C3-P2-Pt & $37(1)$ \\
C3-P2-Pt-P1 & $-7(1)$ \\
P2-Pt-P1-C1 & $11(1)$ \\
\hline
\end{tabular}




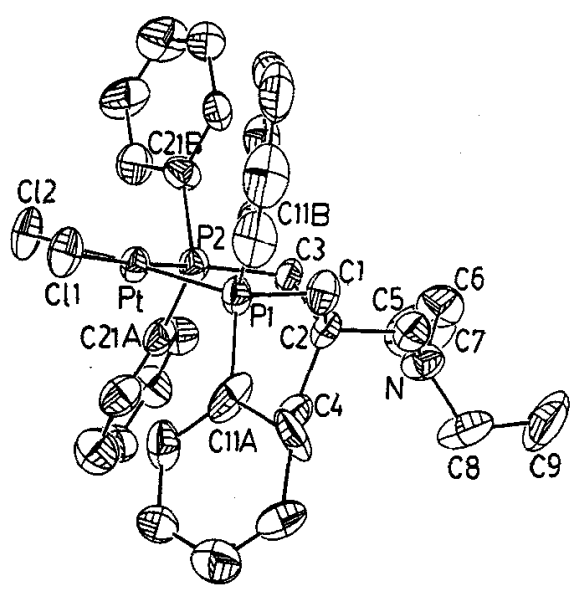

FIGURE 3 Another view of $\left(\mathrm{P}_{2} \mathrm{~N}\right) \mathrm{PtCl}_{2}$.

\section{EXPERIMENTAL}

Nuclear magnetic resonance spectra were recorded on a Bruker AC 200 spectrometer. Phosphorus-31 NMR spectra were determined at a spectrometer frequency of $81.01 \mathrm{MHz}$ and chemical shifts were given in parts per million (ppm) relative to $85 \% \mathrm{H}_{3} \mathrm{PO}_{4}$ in $\mathrm{CDCl}_{3}$. A Perkin-Elmer $983 \mathrm{G}$ instrument was used to obtain infrared spectra.

All of the reactions, manipulations, and purification steps involving phosphines were performed under a nitrogen atmosphere. Air-sensitive liquids were transferred by flexneedles using nitrogen pressure or by syringe. All concentrations of solutions were carried out on a rotary evaporator with water aspirator pressure. Solutions were dried with anhydrous, degassed magnesium sulfate.

Tetrahydrofuran and diethyl ether were distilled under nitrogen from benzophenone ketyl. Other solvents and chemicals from commercial sources were used without further purification, except as noted.

5-Azidomethyl-2,2,5-trimethyl-1,3-dioxane (8). A mixture of tosylate $7(37.71 \mathrm{~g}, 0.12 \mathrm{~mol})$ and sodium azide $(23.41 \mathrm{~g}, 0.36 \mathrm{~mol})$ in DMF $(200 \mathrm{~mL})$ and water $(20 \mathrm{~mL})$ was heated in an oil bath at $100^{\circ} \mathrm{C}$ for $40 \mathrm{~h}$. The reaction mixture was poured into ice-water $(400 \mathrm{~mL})$ and extracted with ether $(150 \mathrm{~mL} \times$ $3)$. The organic extracts were washed with brine, dried and concentrated. The residue was chromatographed on silica gel $(100 \mathrm{~g})$ with elution of $20 \%$ of ethyl acetate in hexane. The eluent was collected and concentrated to give the desired product 8 as a clear, colorless liquid $(17.05 \mathrm{~g}, 75 \%):{ }^{\mathrm{t}} \mathrm{H}$ NMR $\delta$ $3.52(\mathrm{~s}, 4 \mathrm{H}), 3.42(\mathrm{~s}, 2 \mathrm{H}), 1.36(\mathrm{~s}, 3 \mathrm{H}), 1.33(\mathrm{~s}, 3 \mathrm{H}), 0.76(\mathrm{~s}, 3 \mathrm{H})$.

Anal. Calcd for $\mathrm{C}_{8} \mathrm{H}_{15} \mathrm{~N}_{3} \mathrm{O}_{2}: \mathrm{C}, 51.88 ; \mathrm{H}, 8.16 ; \mathrm{N}, 22.69$. Found $\mathrm{C}, 51.84 ; \mathrm{H}, 8.25 ; \mathrm{N}, 23.12$.

5-Aminomethyl-2,2,5-trimethyl-1,3-dioxane (9). A solution of azide 8 (10.75 g, $58.1 \mathrm{mmol})$ in THF $(50 \mathrm{~mL})$ was added dropwise to a suspension of $\mathrm{LiAlH}_{4}(3.26 \mathrm{~g}, 83.8 \mathrm{mmol})$ in THF $(250 \mathrm{~mL})$ at icebath temperature. After addition, the reaction mixture was allowed to warm to room temperature and then heated to reflux for $3 \mathrm{~h}$. A $6 \mathrm{~N} \mathrm{NaOH}$ aqueous solution was slowly added to the mixture with stirring. All aluminum salt became white precipitates. The liquid phase was decanted, dried and concentrated, The residue was distilled to give the amine product 9 as a colorless liquid $(8.22 \mathrm{~g}, 88 \%):$ bp $34-36^{\circ} \mathrm{C} / 0.15-0.22 \mathrm{mmHg} ;{ }^{1} \mathrm{H}$ NMR $\delta 3.62(\mathrm{~d}, J=9 \mathrm{~Hz}, 2 \mathrm{H}), 3.58(\mathrm{~d}, J=9 \mathrm{~Hz}, 2 \mathrm{H}), 2.78(\mathrm{~s}, 2 \mathrm{H})$, $1.50(\mathrm{~s}, 2 \mathrm{H}), 1.43(\mathrm{~s}, 3 \mathrm{H}), 1.38(\mathrm{~s}, 3 \mathrm{H}), 0.81(\mathrm{~s}, 3 \mathrm{H})$.

Anal. Calcd for $\mathrm{C}_{8} \mathrm{H}_{17} \mathrm{NO}_{2}$ : C, 60.35; $\mathrm{H}, 10.76 ; \mathrm{N}, 8.80$. Found $\mathrm{C}, 60.06 ; \mathrm{H}, 10.84 ; \mathrm{N}, 8.69$.

5-(N,N-Diethylaminomethyl)-2,2,5-trimethyl-1,3-dioxane (10). A solution of amine $9(8.54 \mathrm{~g}, 54 \mathrm{mmol})$, ethyl iodide $(15.5 \mathrm{~mL}, 30.2 \mathrm{~g}, 194 \mathrm{mmol})$ and $\mathrm{K}_{2} \mathrm{CO}_{3}(8.18 \mathrm{~g}, 59.3 \mathrm{mmol})$ in absolute ethanol $(80 \mathrm{~mL})$ was heated to reflux for $16 \mathrm{~h}$. After concentration of the solution, $10 \% \mathrm{NaOH}$ solution $(20 \mathrm{~mL})$ was added and extracted with dichloromethane $(30 \mathrm{ml} \times 3)$. The organic extracts were washed with brine, dried, concentrated and distilled under vacuum to give 10 as a colorless liquid $(8.83 \mathrm{~g}, 76 \%)$ : bp 62 $64^{\circ} \mathrm{C} / 0.15-0.20 \mathrm{mmHg}$; ' $\mathrm{H}$ NMR $\delta 3.65(\mathrm{~d}, J=12 \mathrm{~Hz}, 2 \mathrm{H}), 3.50(\mathrm{~d}, J=12 \mathrm{~Hz}, 2 \mathrm{H}), 2.51(\mathrm{q}, J=$ $7 \mathrm{~Hz}, 4 \mathrm{H}), 2.44(\mathrm{~s}, 2 \mathrm{H}), 1.42(\mathrm{~s}, 3 \mathrm{H}), 1.39(\mathrm{~s}, 3 \mathrm{H}), 0.99(\mathrm{t}, J=7 \mathrm{~Hz}, 6 \mathrm{H}), 0.81(\mathrm{~s}, 3 \mathrm{H})$.

Anal. Calcd for $\mathrm{C}_{12} \mathrm{H}_{25} \mathrm{NO}_{2}: \mathrm{C}, 66.93 ; \mathrm{H}, 11.70 ; \mathrm{N}, 6.50$. Found $\mathrm{C}, 66.87 ; \mathrm{H}, 11.54 ; \mathrm{N}, 6.52$. 
2-(N,N-Diethylaminomethyl)-2-methyl-1,3-propanediol (11). Compound $10(4.84 \mathrm{~g}, 22.5 \mathrm{mmol})$ in THF $(12 \mathrm{~mL})$ was allowed to react with water $(4 \mathrm{~mL})$ in the presence of concentrated $\mathrm{HCl}(2.2 \mathrm{~mL})$ at refluxing temperature for $8 \mathrm{~h}$. The reaction mixture was neutralized with $\mathrm{NaOH}$ and the organic layer was separated. The aqueous portion was extracted with THF $(2 \times 10 \mathrm{~mL})$ and the combined organic extracts were dried and concentrated. Distillation of the residue gave 11 as a colorless, viscous liquid $(3.83 \mathrm{~g}, 97 \%)$ : bp $91-92^{\circ} \mathrm{C} / 250-300 \mu \mathrm{mHg}$; ${ }^{1} \mathrm{H}$ NMR $\delta 5.27(\mathrm{br}, 2 \mathrm{H}), 3.66(\mathrm{~d}, J=11 \mathrm{~Hz}, 2 \mathrm{H})$, $3.54(\mathrm{~d}, J=11 \mathrm{~Hz}, 2 \mathrm{H}), 2.55(\mathrm{q}, J=7 \mathrm{~Hz}, 4 \mathrm{H}), 2.54(\mathrm{~s}, 2 \mathrm{H}), 1.05(\mathrm{t}, J=7 \mathrm{~Hz}, 6 \mathrm{H}), 0.80(\mathrm{~s}, 3 \mathrm{H})$. Anal. Calcd for $\mathrm{C}_{9} \mathrm{H}_{21} \mathrm{NO}_{2}: \mathrm{C}, 61.68 ; \mathrm{H}, 12.08 ; \mathrm{N}, 7.99$. Found $\mathrm{C}, 61.44 ; \mathrm{H}, 12.04 ; \mathrm{N}, 7.98$.

$N, N$-Diethyl-2,2-bis(diphenylphosphinomethyl)propanamine (3). A $2.5 \mathrm{M}$ hexane solution of $n$-butyllithium $(11.7 \mathrm{~mL}, 29.3 \mathrm{mmol})$ was added to a solution of diol $11(2.33 \mathrm{~g}, 13.3 \mathrm{mmol})$ in THF $(100$ $\mathrm{mL}$ ) at $0^{\circ} \mathrm{C}$. After addition, the solution was allowed to stir for another $30 \mathrm{~min}$. Methanesulfonyl chloride $(3.12 \mathrm{~g}, 27.3 \mathrm{mmol}$ ) was then added to the above solution to yield a white suspension (A). A diphenylphosphide solution (B) was prepared by addition of a $2.5 \mathrm{M}$ hexane solution of $n$-butyllithium $(12.0 \mathrm{~mL}, 30.0 \mathrm{mmol})$ to the solution of diphenylphosphine $(5.46 \mathrm{~g}, 29.3 \mathrm{mmol})$ in THF $(60 \mathrm{~mL})$. The solution (B) was slowly transferred into the solution (A) by flexible needle under nitrogen atmosphere. The resulting mixture was stirred at room temperature for $16 \mathrm{~h}$ and water $(25 \mathrm{~mL})$ was added to quench the anion. The organic layer was separated, dried and concentrated. The residue was chromatographed on alumina $(80 \mathrm{~g})$ with elution by $10 \%$ and $30 \%$ dichloromethane in hexane. The fraction of $30 \%$ $\mathrm{CH}_{2} \mathrm{Cl}_{2}$ eluent was collected and concentrated to give 3 as a colorless, viscous liquid $(5.16 \mathrm{~g}, 76 \%)$ : ${ }^{1} \mathrm{H}$ NMR $\delta 7.46-7.24(\mathrm{~m}, 20 \mathrm{H}), 2.59(\mathrm{~d}, J=7 \mathrm{~Hz}, 2 \mathrm{H}), 2.53(\mathrm{~d}, J=7 \mathrm{~Hz}, 2 \mathrm{H}), 2.47(\mathrm{~s}, 2 \mathrm{H}), 2.35(\mathrm{q}$, $J=7 \mathrm{~Hz}, 4 \mathrm{H}), 0.91(\mathrm{t}, J=7 \mathrm{~Hz}, 6 \mathrm{H}), 0.87(\mathrm{~s}, 3 \mathrm{H}) ;{ }^{31} \mathrm{P}$ NMR $\delta-25.02$.

Anal. Calcd for $\mathrm{C}_{33} \mathrm{H}_{39} \mathrm{NP}_{2}: \mathrm{C}, 77.47 ; \mathrm{H}, 7.68 ; \mathrm{N}, 2.74$. Found $\mathrm{C}, 77.06 ; \mathrm{H}, 7.43 ; \mathrm{N}, 2.72$.

5-Benzoxymethyl-2,2,5-trimethyl-1,3-dioxane (12). Fresh-cut sodium metal $(0.5 \mathrm{~g}, 21.7 \mathrm{mmol})$ was added to a solution of alcohol $6(2.97 \mathrm{~g}, 18.6 \mathrm{mmol})$ in dried toluene $(30 \mathrm{~mL})$ and the resulting suspension was heated to reflux for $6 \mathrm{~h}$. To this solution was added benzyl chloride $(2.53 \mathrm{~g}, 20.0 \mathrm{mmol})$ and then refluxed for another $12 \mathrm{~h}$. The reaction mixture was quenched with water $(10 \mathrm{~mL})$ and the organic layer was separated. The aqueous layer was extracted with dichloromethane $(30 \mathrm{~mL} \times 3)$ and both organic portions were combined. Concentration and distillation provided $\mathbf{1 2}$ as a colorless liquid (3.7 $\mathrm{g}, 80 \%$ ): bp $94-96^{\circ} \mathrm{C} / 70 \mu \mathrm{m} \mathrm{Hg}$; ${ }^{1} \mathrm{H}$ NMR $\delta 7.33-7.27(\mathrm{~m}, 5 \mathrm{H}), 4.53(\mathrm{~s}, 2 \mathrm{H}), 3.73(\mathrm{~d}, J=11 \mathrm{~Hz}$, $2 \mathrm{H}), 3.54(\mathrm{~d}, J=11 \mathrm{~Hz}, 2 \mathrm{H}), 3.46(\mathrm{~s}, 2 \mathrm{H}), 1.42(\mathrm{~s}, 3 \mathrm{H}), 1.37(\mathrm{~s}, 3 \mathrm{H}), 0.89(\mathrm{~s}, 3 \mathrm{H})$; HRMS Calcd for $\mathrm{C}_{15} \mathrm{H}_{22} \mathrm{O}_{3} \mathrm{~m} / \mathrm{e} 250.15688$. Found $\mathrm{m} / \mathrm{e} 250.1557$.

2-Benzoxymethyl-2-methyl-1,3-bis(methanesulfonyloxy)propane (14). A mixture of $12(2.42 \mathrm{~g}, 9.68$ $\mathrm{mmol})$, water $(5 \mathrm{~mL})$, methanol $(5 \mathrm{~mL})$ and few drops of concentrated hydrochloric acid was heated to reflux for $1 \mathrm{~h}$. Dichloromethane was added and the organic layer was separated, dried and concentrated. The crude product of diol 13 was re-dissolved in a solution of dichloromethane $(60 \mathrm{~mL})$ and triethylamine ( $4 \mathrm{~mL}, 2.9 \mathrm{~g}, 28.7 \mathrm{mmol})$. Methanesulfonyl chloride $(2.44 \mathrm{~g}, 21.3 \mathrm{mmol})$ was slowly added to the above solution and the resulting mixture was stirred at room temperature for $1 \mathrm{~h}$. The reaction mixture was washed with $10 \% \mathrm{NaOH}$ solution $(50 \mathrm{~mL})$, brine, and saturated $\mathrm{NaHCO}_{3}$ solution. The organic portion was dried, concentrated and chromatographed on silica $(10 \mathrm{~g})$ with elution by dichloromethane. The eluent was collected and concentrated to obtain a viscous liquid as compound 14 (3.3 g, 93\%): 'H NMR $87.34-7.29(\mathrm{~m}, 5 \mathrm{H}), 4.48(\mathrm{~s}, 2 \mathrm{H}), 4.13(\mathrm{~s}, 4 \mathrm{H}), 3.36(\mathrm{~s}, 2 \mathrm{H}), 2.97(\mathrm{~s}, 6 \mathrm{H}), 1.06(\mathrm{~s}$, $3 \mathrm{H}$ ); HRMS Calcd for $\mathrm{C}_{14} \mathrm{H}_{22} \mathrm{O}_{7} \mathrm{~S}_{2} \mathrm{~m} / \mathrm{e} 366.08068$. Found $\mathrm{m} / \mathrm{e} 366.0807$.

2,2-Bis(azidomethyl)-1-benzoxypropane (15). A mixture of methanesulfonate 14 ( $7.45 \mathrm{~g}, 20.4 \mathrm{mmol}$ ), $\mathrm{NaN}_{3}(7.95 \mathrm{~g}, 122 \mathrm{mmol})$, water $(10 \mathrm{~mL})$ and DMF $(100 \mathrm{~mL})$ was heated at $110^{\circ} \mathrm{C}$ for $48 \mathrm{~h}$. The reaction mixture was poured into ice water $(100 \mathrm{~mL})$ and extracted with ether $(50 \mathrm{~mL} \times 3)$. The ether extracts were dried and concentrated and the remaining material was chromatographed on silica gel $(50 \mathrm{~g})$. The elution of $5 \%$ ethyl acetate in hexane gave 15 as a colorless liquid after concentration $(4.82 \mathrm{~g}, 91 \%)$ : Ir $\left(\mathrm{CH}_{2} \mathrm{Cl}_{2}\right) 2103 \mathrm{~cm}^{-1}$; ${ }^{1} \mathrm{H}$ NMR $87.35-7.25(\mathrm{~m}, 5 \mathrm{H}), 4.49(\mathrm{~s}, 2 \mathrm{H}), 3.28(\mathrm{~s}, 2 \mathrm{H}), 3.25(\mathrm{~s}, 4 \mathrm{H}), 0.96$ $(\mathrm{s}, 3 \mathrm{H})$.

Anal. Calcd for $\mathrm{C}_{12} \mathrm{H}_{10} \mathrm{~N}_{6} \mathrm{O}: \mathrm{C}, 55.37 ; \mathrm{H}, 6.2 ; \mathrm{N}, 32.39$. Found $\mathrm{C}, 55.07 ; \mathrm{H}, 6.0 ; \mathrm{N}, 32.60$.

1-Benzoxy-2,2-bis( $N, N$-diethylaminomethyl)propane (17). Raney Nickel $(6.5 \mathrm{~g})$ was washed with methanol to remove water and was placed in a round-bottom flask containing isopropanol $(50 \mathrm{~mL})$. The suspension was heated at $60^{\circ} \mathrm{C}$ for $30 \mathrm{~min}$ and azide $15(5.1 \mathrm{~g}, 19.6 \mathrm{mmol})$ in isopropanol $(10 \mathrm{~mL})$ was slowly added to the mixture. After stirring for $4 \mathrm{~h}$ at room temperature, the reaction mixture was filtered and the filtrate was concentrated to give colorless liquid $(3.55 \mathrm{~g}, 89 \%)$ : ir $(\mathrm{NaCl}) 3370,3300 \mathrm{~cm}^{-1} ;{ }^{1} \mathrm{H}$ NMR $\delta 7.38-7.27(\mathrm{~m}, 5 \mathrm{H}), 4.45(\mathrm{~s}, 2 \mathrm{H}), 3.25(\mathrm{~s}, 2 \mathrm{H}), 2.60(\mathrm{~s}, 4 \mathrm{H}), 1.45-1.25(\mathrm{br}, 4 \mathrm{H}), 0.80(\mathrm{~s}, 3 \mathrm{H})$. This amine product 16 was used for alkylation without further purification. Thus $16(3.4 \mathrm{~g})$ dissolved in a mixture of $\mathrm{K}_{2} \mathrm{CO}_{3}(5.0 \mathrm{~g}, 36.2 \mathrm{mmol})$, ethyl iodide $(15.21 \mathrm{~g}, 97.5 \mathrm{mmol})$ and ethanol $(60 \mathrm{~mL})$ and the 
resulting mixture was heated for refluxing overnight. After removal of all solvent, the remaining material was treated with $1 \mathrm{~N} \mathrm{NaOH}$ solution $(50 \mathrm{~mL})$ and extracted with ether $(30 \mathrm{~mL} \times 3)$. The organic extracts were dried, concentrated and chromatographed on alumina $(50 \mathrm{~g})$. The eluent of $5 \%$ ethyl acetate in hexane was collected and concentrated to the amine 17 as a colorless liquid $(4.23 \mathrm{~g}, 80 \%)$ : 'H NMR $\delta 7.32-7.30(\mathrm{~m}, 5 \mathrm{H}), 4.41(\mathrm{~s}, 2 \mathrm{H}), 3.25(\mathrm{~s}, 2 \mathrm{H}), 2.48(\mathrm{q}, J=7 \mathrm{~Hz}, 8 \mathrm{H}), 2.35(\mathrm{~d}, J=14$ $\mathrm{Hz}, 2 \mathrm{H}), 2.16(\mathrm{~d}, J=14 \mathrm{~Hz}, 2 \mathrm{H}), 0.93(\mathrm{t}, J=7 \mathrm{~Hz}, 12 \mathrm{H}), 0.84(\mathrm{~s}, 3 \mathrm{H})$.

Anal. Calcd for $\mathrm{C}_{20} \mathrm{H}_{36} \mathrm{~N}_{2} \mathrm{O}$ : C, 74.95; H, 11.32; N, 8.74. Found C, 74.52; H, 11.08; N, 8.51.

2,2-Bis $(N, N$-diethylaminomethyl)-propan-1-ol (18). Lithium naphthalenide was prepared by the addition of lithium $(50 \mathrm{mg}, 7.14 \mathrm{mmol})$ into a solution of naphthalene $(0.8 \mathrm{~g}, 6.25 \mathrm{mmol})$ in THF (60 $\mathrm{mL}$ ) with stirring for $3 \mathrm{~h}$. Compound $17(0.79 \mathrm{~g}, 2.47 \mathrm{mmol})$ in THF (10 mL) was added to the above solution and the mixture was stirred at room temperature for another $2 \mathrm{~h}$. Methanol ( $2 \mathrm{~mL})$ was added to quench the reaction. The mixture was acidified with $1 \mathrm{~N} \mathrm{HCl}$ solution and extracted with ether to remove naphthalene. The aqueous portion was then adjusted to the $\mathrm{pH}$ of 12 by $\mathrm{NaOH}$ and extracted with ether $(30 \mathrm{~mL} \times 3)$. The ether extracts were dried, concentrated and chromatographed on alumina $(5 \mathrm{~g})$ to give 18 as light-yellow liquid $(0.49 \mathrm{~g}, 88 \%)$ : ${ }^{1} \mathrm{H}$ NMR $\delta 3.53(\mathrm{~s}, 2 \mathrm{H}), 2.50(\mathrm{~s}, 1 \mathrm{H}), 2.50(\mathrm{~d}, J$ $=14 \mathrm{~Hz}, 2 \mathrm{H}), 2.45(\mathrm{q}, J=7 \mathrm{~Hz}, 2 \mathrm{H}), 2.15(\mathrm{~d}, J=14 \mathrm{~Hz}, 2 \mathrm{H}), 0.97(\mathrm{t}, J=7 \mathrm{~Hz}, 12 \mathrm{H}), 0.92(\mathrm{~s}$, $3 \mathrm{H}$ ); HRMS Calcd for $\mathrm{C}_{13} \mathrm{H}_{30} \mathrm{ON}_{2} \mathrm{~m} / \mathrm{e} 230.2358$. Found $\mathrm{m} / \mathrm{e} 230.2361$.

2,2-Bis $(N, N$-diethylaminomethyl)-1-diphenylphosphinopropane (4). A solution of 18 (1.21 g, 5.26 mmol) in THF $(40 \mathrm{~mL})$ was treated with $n$-butyllithium $(2.2 \mathrm{M}, 2.42 \mathrm{~mL}, 5.32 \mathrm{mmol})$ followed by methanesulfonyl chloride $(0.62 \mathrm{~g}, 5.4 \mathrm{mmol})$ with stirring for $30 \mathrm{~min}$. The diphenylphosphide anion, prepared by adding $2.2 \mathrm{M} n$-buthyllithium $(2.42 \mathrm{~mL}, 5.32 \mathrm{mmol})$ to a solution of diphenylphosphine $(0.98 \mathrm{~g}$, $5.29 \mathrm{mmol})$ in THF $(20 \mathrm{~mL})$, was added to the above solution at room temperature and then heated to reflux for $4 \mathrm{~h}$. Degassed water $(15 \mathrm{~mL})$ was added and the organic layer was separated. The aqueous layer was extracted with THF $(20 \mathrm{~mL} \times 2)$ and the combined extracts were dried and concentrated to give a viscous oil. This was chromatographed on alumina $(50 \mathrm{~g})$ with ethyl acetate-hexane $(1: 20)$ to give the desired product 4 as a colorless oil $(1.05 \mathrm{~g}, 50 \%)$ : ${ }^{1} \mathrm{H}$ NMR $\delta 7.46-7.24(\mathrm{~m}, 10 \mathrm{H}), 2.52-2.27$ $(\mathrm{m}, 14 \mathrm{H}), 0.91(\mathrm{t}, J=6.8 \mathrm{~Hz}, 12 \mathrm{H}), 0.82(\mathrm{~s}, 3 \mathrm{H}) ;{ }^{31} \mathrm{P}$ NMR $\delta-24.95$.

Anal. Calcd for $\mathrm{C}_{25} \mathrm{H}_{39} \mathrm{~N}_{2} \mathrm{P}: \mathrm{C}, 75.34 ; \mathrm{H}, 9.86 ; \mathrm{N}, 7.03$. Found $\mathrm{C}, 75.51 ; \mathrm{H}, 10.18 ; \mathrm{N}, 6.88$.

Dichloro $\{N, N$-diethyl-2,2-bis(diphenylphosphinomethyl)propanamine $\}$ palladium(II) (21). A mixture of diphosphine $3(43.7 \mathrm{mg}, 0.085 \mathrm{mmol})$ and palladium(II) chloride (17.0 $\mathrm{mg}, 0.096 \mathrm{mmol})$ in dichloromethane $(8 \mathrm{~mL})$ was stirred overnight. The reaction mixture was concentrated to a volume of $4 \mathrm{~mL}$ and hexane $(10 \mathrm{~mL})$ was added. Upon standing, a yellow solid was formed and centrifuged. The solid was washed with acetone and dried to give complex 21 as a light yellow solid (54.7 $\mathrm{mg}, 93 \%)$ : $\mathrm{mp} 237-$ $241^{\circ} \mathrm{C}$ (dec.); ${ }^{1} \mathrm{H}$ NMR $\delta 8.24-7.40(\mathrm{~m}, 20 \mathrm{H}), 2.48(\mathrm{~s}, 2 \mathrm{H}), 2.46(\mathrm{q}, J=7 \mathrm{~Hz}, 4 \mathrm{H}), 2.26-2.15(\mathrm{~m}$, $4 \mathrm{H}), 0.87(\mathrm{t}, J=7 \mathrm{~Hz}, 6 \mathrm{H}), 0.22(\mathrm{~s}, 3 \mathrm{H})$.

Dichloro\{2,2-bis(N,N-diethylaminomethyl)-1-diphenylphosphinopropane\}palladium(II) (22). This complex was prepared by a similar procedure as described for 21 . Complex 22 was obtained as a yellow solid (94\%): $\mathrm{mp} 113-115^{\circ} \mathrm{C}$ (dec.); ' $\mathrm{H}$ NMR $\delta 8.22-7.24(\mathrm{~m}, 10 \mathrm{H}), 4.60-4.49(\mathrm{~m}, 1 \mathrm{H}), 4.04-3.95(\mathrm{~m}$, $1 \mathrm{H}), 3.57-3.46(\mathrm{~m}, 1 \mathrm{H}), 2.63-2.36(\mathrm{~m}, 7 \mathrm{H}), 2.20(\mathrm{~s}, 2 \mathrm{H}), 2.12-1.98(\mathrm{~m}, 2 \mathrm{H}), 1.87(\mathrm{t}, J=7 \mathrm{~Hz}, 3 \mathrm{H})$, $1.11(\mathrm{t}, J=7 \mathrm{~Hz}, 3 \mathrm{H}), 0.92(\mathrm{t}, J=7 \mathrm{~Hz}, 6 \mathrm{H}), 0.82(\mathrm{~s}, 3 \mathrm{H}), 5.3\left(\mathrm{CH}_{2} \mathrm{CL}_{2}\right)$.

Dichloro $\{N, N$-diethyl-2,2-bis(diphenylphosphinomethyl)propanamine $\}$ platinum(II) (23). A mixture of $\mathrm{K}_{2} \mathrm{PtCl}_{4}(63.6 \mathrm{mg}, 0.153 \mathrm{mmol}), \mathbf{P}_{2} \mathrm{~N}(75.0 \mathrm{mg}, 0.147 \mathrm{mmol})$ and tetrabutylammonium bromide $(5.7$ $\mathrm{mg}, 0.018 \mathrm{mmol})$ in dichloromethane $(8 \mathrm{~mL})$ and water $(3 \mathrm{~mL})$ was stirred at room temperature overnight. The organic layer was separated, dried and concentrated to a volume of $4 \mathrm{~mL}$. Hexane (10 $\mathrm{mL}$ ) was added to the solution and was allowed to stand overnight. A white crystalline solid (102.8 $\mathrm{mg}, 90 \%$ ) was obtained and identified as the desired complex $23: \mathrm{mp} 230-234^{\circ} \mathrm{C}$ (dec.); ${ }^{1} \mathrm{H}$ NMR $\delta$ $8.23-7.40(\mathrm{~m}, 20 \mathrm{H}), 2.47(\mathrm{~s}, 2 \mathrm{H}), 2.45(\mathrm{q}, J=7 \mathrm{~Hz}, 4 \mathrm{H}), 2.27-2.15(\mathrm{~m}, 4 \mathrm{H}), 0.86(\mathrm{t}, J=7 \mathrm{~Hz}, 6$ $\mathrm{H}), 0.23(\mathrm{~s}, 3 \mathrm{H})$.

Dichloro $\{2,2-$ bis $(N, N$-diethylaminomethyl)-I-diphenylphosphinopropane $\}$ platinum(II) (24). This complex was prepared by a similar procedure as described for 23. Complex 24 is a light-yellow solid: mp $177-185^{\circ} \mathrm{C}(\mathrm{dec}){ }^{1} \mathrm{H}$ NMR $88.20-7.25(\mathrm{~m}, 10 \mathrm{H}), 4.60-4.40(\mathrm{~m}, 1 \mathrm{H}), 4.15-4.00(\mathrm{~m}, 1 \mathrm{H}), 3.75-3.60$ $(\mathrm{m}, 1 \mathrm{H}), 2.90-2.60(\mathrm{~m}, 3 \mathrm{H}), 2.52(\mathrm{q}, J=6.8 \mathrm{~Hz}, 4 \mathrm{H}), 2.18(\mathrm{~s}, 2 \mathrm{H}), 2.15-2.00(\mathrm{~m}, 2 \mathrm{H}), 1.80(\mathrm{t}, J=$ $6.8 \mathrm{~Hz}, 3 \mathrm{H}), 1.11(\mathrm{t}, J=7 \mathrm{~Hz}, 3 \mathrm{H}), 0.94(\mathrm{t}, J=6.8 \mathrm{~Hz}, 6 \mathrm{H}), 0.88(\mathrm{~s}, 3 \mathrm{H})$.

All ${ }^{31} \mathrm{P}$ NMR data and elemental analysis data of complexes 21-24 are listed in Table $\mathrm{I}$. 
TABLE III

Atomic coordinates and thermal parameters.

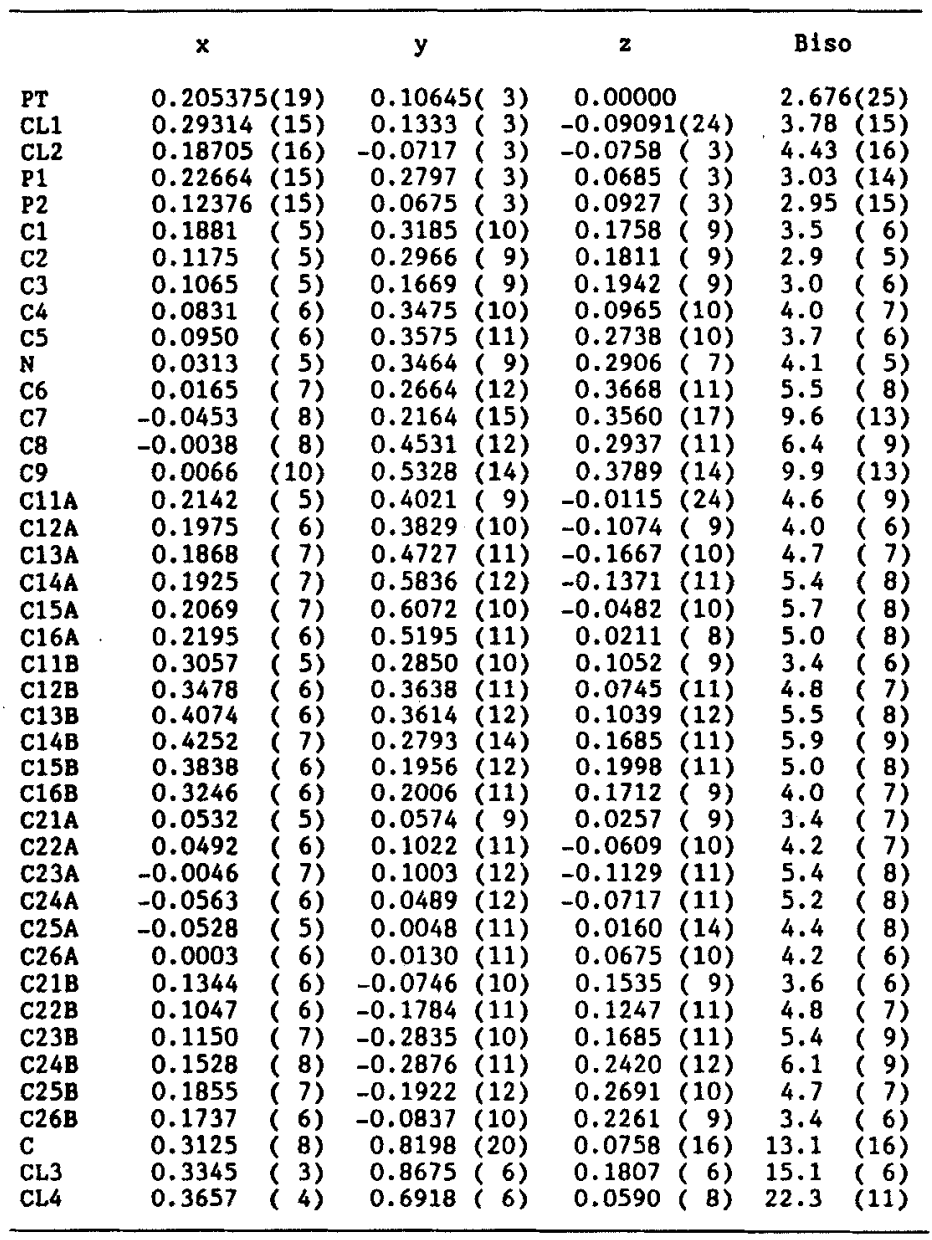

\section{Crystallography}

Measurement of cell dimensions and data collections were performed on an Enraf-Nonius CAD-4 diffractometer. Formula $\mathrm{C}_{33} \mathrm{H}_{39} \mathrm{Cl}_{2} \mathrm{NP}_{2} \mathrm{Pt} \cdot \mathrm{CH}_{2} \mathrm{Cl}_{2}$. Crystal size $0.31 \times 0.38 \times 0.3(\mathrm{~mm})$. Space group Pca2 ${ }_{1}$. Cell parameters: $a=21.983(5), b=11.419(1), c=14.179(3) \AA, V=3559(1) \AA^{3}, T=300$ $\mathrm{K}, Z=4, D_{x}=1.61 \mathrm{Mg} \mathrm{m}^{-3}, D_{m}=1.60 \mathrm{Mg} \mathrm{m}^{-3}, \mathrm{~F}(000)=1712, \mu=4.24 \mathrm{~mm}^{-1}, \lambda=0.7107 \AA$. A total 3262 unique reflections were measured, of which 2826 [I $>2.0 \sigma(\mathrm{I})]$ were observed. Transmission factors were $0.762-1.0$. Heavy atom method was used for solving structure. Refinement: $F_{o}$ and $F_{c}$ are the observed and calculated structure factor amplitudes, respectively. The function minimized was $\Sigma w\left(F_{o}-F_{c}\right)^{2}$, where $w=1 / \sigma^{2}\left(F_{o}\right)$, or $\left(F_{o}\right)$ from counting statistics; $R_{f}=\Sigma / F_{o}-F_{c} / \Sigma\left(F_{o}\right) ; R_{w}=$ $\left[\Sigma w\left(F_{o}-F_{c}\right)^{2} / \Sigma w\left(F_{o}\right)^{2}\right]^{1 / 2} ; S=\left[\Sigma\left(w\left(F_{o}-F_{c}\right)^{2}\right) /(\text { No. of reflections - No. of params })\right]^{1 / 2}$. For significant reflections, $R_{F}=0.039, R_{w}=0.033, S=2.88$. Atomic scattering factors were taken from International Table for X-ray Crystallography. ${ }^{8}$ NRCC SDP VAX package was the computing program used. ${ }^{9}$ The atomic coordinates and thermal parameters are given in Table III. Lists of thermal parameters and structure factors are available from the authors.

\section{ACKNOWLEDGMENT}

We thank National Science Council of R.O.C. (NSC80-0208-M002-32) for financial support. 


\section{REFERENCES}

1. W. J. Knebel and R. J. Angelici, Inorg. Chem., 13, 627 (1974); M. K. Cooper and J. M. Downes, J. Chem. Soc., Chem. Commun., 381 (1981); G. J. Organ, M. K. Cooper, K. Henrick and M. McPartlin, J. Chem. Soc., Dalton Trans. 2377 (1984); D. Hedden, D. M. Roundhill, W. C. Fultz and A. L. Rheingold, J. Am. Chem. Soc., 106, 5014 (1984); W. de Graaf, S. Harder, J. Boersma and G. van Koten, J. Organomet. Chem., 358, 545 (1988); F. Balegroune, P. Braunstein, D. Grandjean, D. Matt and D. Nobel, Inorg. Chem., 27, 3320 (1988); A. A. H. van der Zeijden, G. van Koten, J. M. Ernsting, C. J. Elsevier, B. Krijnen and C. H. Stam, J. Chem. Soc., Dalton Trans., 317 (1989); S. Park, M. P. Johnson and D. M. Roundhill, Organometallics, 8, 1700 (1989); M. D. Fryzuk and C. D. Montgomery, Coord. Chem. Rev., 95, 1 (1989), R. Bhula, P. Osvath and D. C. Weatherburn, Coord. Chem. Rev., 91, 89 (1988), and references therein.

2. S.-T. Liu, C.-L. Tsao, M.-C. Cheng and S.-M. Peng, Polyhedron, 9, 2579 (1990).

3. S.-T. Liu and K.-J. Liu. Inorg. Chem., 29, 4576 (1990).

4. S.-T. Liu, G.-J. Liu, C.-H. Yieh, M.-C. Cheng and S.-M. Peng, Organomet. Chem., 387, 83 (1990).

5. S.-T. Liu, H.-E. Wang, M.-C. Cheng and S.-M. Peng, J. Organomet. Chem., 376, 333 (1989).

6. V. W. Gash, J. Org. Chem., 37, 719 (1972).

7. G. G. Messmer, E. L. Amma and J. A. Ibers, Inorg. Chem., 19, 2437 (1980).

8. International Tables for X-ray Crystallography, Vol. IV Kynoch Press, Birmingham, 1974.

9. E. J. Gabe and F. L. Lee, Acta Cryst., A37, S 339 (1981). 